\title{
RUANG PERTUKARAN IDE DI BANDUNG WETAN
}

\author{
Muhammad Ricky Siswanto ${ }^{1)}$, Mieke Choandi ${ }^{21}$ \\ 1) Program Studi S1 Arsitektur, Fakultas Teknik, Universitas Tarumanagara, rixzibix999@gmail.com \\ 2) Program Studi S1 Arsitektur, Fakultas Teknik, Universitas Tarumanagara, mieke@untar.ac.id
}

\begin{abstract}
Abstrak
Bandung wetan dikenal memiliki banyak distro dan toko baju yang secara tidak langsung melahirkan banyak desainer ataupun pembuat baju, dengan banyaknya desainer atau pembuat baju yang membutuhkan tempat dimana mereka dapat mencari ide-ide dan bertukar pikiran, oleh karena itu terbangun banyak kafe ataupun restoran dimana mereka dapat mencari ide ataupun bertukar pikiran. Walaupun terdapat berbagai macam kafe dan restoran yang tersedia di wilayah bandung, sebagian banyak dari kafe dan restoran itu memerlukan pengeluaran biaya oleh pengunjung, yang menjadikannya tidak dapat di akses oleh semua kalangan masyarakat ataupun pengunjung dari luar kota itu sendiri, sehubungan dengan hal itu diperlukannya tempat dimana pembuat baju, desainer dan mesyarakat dapat berkumpul ataupun bertukar pikiran tidak peduli umur dan ekonomi mereka, mereka dapat berkumpul dan berbincang tanpa adanya kesenjangan sosial. Third place ini akan membantu pembangunan kebutuhan masyarakat kota dan juga ekonomi kota dalam beberapa tahun kedepan, dengan menaikan ke-kreatifitas yang di hasilkan karena banyaknya tempat dimana meraka dapat mencari inspirasi dan ide-ide. Masyarakat wilayah Bandung Wetan, khususnya Kelurahan Cihapit akan menaikan kualitas kerja, belajar, maupun produk-produk yang dihasilkan oleh masyarakat. Third place atau tempat ketiga adalah salah satu jawaban pendekatan penembangan perkotaan itu sendiri dalam upaya meningkatkan nilai suatu kawasan yang di akibatkan oleh perubahan fungsi dan perubahan pola ruang kota itu sendiri.
\end{abstract}

Kata kunci : bertukar pikiran; pola ruang kota; third place

\begin{abstract}
Bandung Wetan is known to have many distros and clothing stores which indirectly give birth to many designers or clothes makers, with many designers or clothes makers who need a place where they can look for ideas and exchange ideas, therefore many cafes or restaurants are built. can search for ideas or exchange ideas. Although there are a variety of cafes and restaurants available in the Bandung area, most of the cafes and restaurants require expenses by visitors, which makes it inaccessible to all members of the community or visitors from outside the city itself, in connection with this need a place where clothing makers, designers and communities can gather or exchange ideas no matter their age and economy, they can gather and talk without social gaps. This third place will help the development of the needs of the city community and also the city's economy in the next few years, by increasing the creativity generated by the many places where they can look for inspiration and ideas. The people of the Bandung Wetan area, especially the Cihapit Village will increase the quality of work, study, and products produced by the community. Third place or third place is one of the answers to the approach of urban development itself in an effort to increase the value of an area caused by changes in functions and changes in the pattern of urban space itself.
\end{abstract}

Keywords : brainstorm; city room pattern; third place

\section{PENDAHULUAN}

Kota Bandung yang memiliki banyak distro dan toko baju yang dimana secara tidak langsung melahirkan banyaknya pembuat baju, ataupun designer yang membutuhkan tempat dimana meraka dapat mendapatkan inspirasi ataupun menambah daya kekreatifan individu itu sendiri, dengan begitu banyak lahirnya tempat dimana mereka dapat menghabiskan waktu mereka untuk merancang dan berpikir agar mendapatkan suatu inspirasi yang kreatif. yang 
menjadikannya banyak terbentuknya kafe, restoran, ataupun tempat berkumpul masyarakat untuk menuangkan ide-idenya dengan orang lain. Dan karena Bandung juga dikenal sebagai tempat kuliner yang cukup banyak menarik wisatawan ataupun turis yang datang ke Bandung maka bertambah banyak pula tempat- tempat kuliner ataupun tempat wisata yang secara tidak langsung merubah infrastruktur kota Bandung itu sendiri.

Dengan banyaknya pembangunan infrastruktur sarana berkumpulnya massa umum yang salah satunya seperti kafe dan juga restoran, menjadi pemicu terjadinya perubahan fisik dari kota itu sendiri, karena adanya faktor peningkatan datangnya wisatawan dan pengunjung dari liuar kota maupun pengunjung asing di Kawasan itu sendiri. Oleh karena itu kafe dan restoran termasuk salah satu Third Place yang terbentuk karena kebiasaan dan kebutuhan masyarakat Bandung.Namun sebagian banyak dari kafe dan restoran itu memerlukan pengeluaran biaya oleh pengunjung, yang menjadikannya tidak dapat di akses oleh semua kalangan masyarakat ataupun pengunjung dari luar kota itu sendiri.

\section{KAJIAN LITERATUR}

\section{The Third Place}

Dalam buku The Great Good Place, Oldenberg (1999) menjelaskan konsepy third place sebagai pembentuk ruang interaksi sosial. Oldenberg mengatakan bahwa third place merupakan tempat dimana manusia yang ingin mengobati stress, kesepian, dan keterasingan. Third place adalah suatu tempat dimana dapat mengatasi kebosanan, dan tidak hanya mengatasi kebosanan manusia didalamnya juga dapat merasakan ketenangan, bersantai dan terhibur di dalamnya.

Third place merupakan tempat dimana orang melarikan diri dari first place (rumah) dan second place (tempat kerja ataupun sekolah) untuk membuka jadi dirinya dan untuk bersosialisasi di dalamnya dengan orang-orang yang juga dating ke third place ini. Dalam penelitian Oldenberg ada 8 (delapan) karakter yang membentuk third place yaitu; On neutral ground (zona netral), Leveler (tidak ada tingkatan), Conversation is the main activity (perbincangan adalah aktiviitas utama), Accessibility and accommodation (aksesibililtas dan akomodasi), The regulars (regulasi), Low profile (profil rendah), Mood is playful (fokus pada keinteraksi), A home away form home (rumah dimana jauh dari rumah).

Bagi masyarakat perkotaan umumnya bersifat individualis, third place merupakan kebutuhan, dimana tempat-tempat tersebut mereka dapat memiliki kesempatan menikmati hubungan sosial dengan orang lain dengan suasana yang santai. ( Ray Oldenberg, The Great Good Place,1999)

\section{Creative City}

Richard Florida (2012) menyatakan bahwa Kota Kreatif adalah "kota yang menciptakan lingkungan yang mendukung orang untuk memikirkan, merencanakan, dan bertindak dengan imajinasi dalam memanfaatkan kesempatan dan masalah kota, mengubah kesempatan menjadi pemecahan." Dimana kota kreatif merupakan jawaban atas semua pertanyaan bagaimana pengembangan kota terjadi, dengan mengungkapkan ide yaitu : (a).Peningkatan Ruang Terbuka Hijau (RTH), (b)."Revitalisasi” (atau gentrifaction) kota tua, (c)Branding kota dengan menekankan gaya hidup, budaya, dan pustaka

Tapi kondisi di atas tidak otomatis menarik individu untuk datang. Pertanyaannya, tidakkah orang akan pergi ke kota di mana ada prospek lapangan kerja, bukan sekedar karena keindahan kotanya? (Kecuali kalau untuk keperluan wisata.) Kota seharusnya memfokuskan pada penyediaan kesempatan kerja yang berkualitas dan setara daripada sekedar menjadi kota yang "Baik" dari branding dan kulitnya saja. Misalnya dengan:

a) Meningkatkan pertumbuhan ekonomi mendasar

b) Meningkatkan kemampuan (skill), keterhubungan (connectivity) dan akses ke pasar dan lapangan kerja dengan lebih meratai 
c) Memastikan warga dapat mengakses kesempatan-kesempatan baru

d) Meningkatkan layanan publik utama, seperti transportasi, tempat tinggal, air bersih, sanitasi, listrik

e) Dukungan pendidikan dan pengembangan kemampuan

Konsep tenaga kerja "kreatif" seringkali dibingkai secara sangat utopia, dikaitkan dengan ketangguhan dan kelincahan anak muda, mampu bekerja sendiri, fleksibel, memiliki berbagai kemahiran dan mobilitas tinggi, dengan portfolio yang mengagumkan. Tapi perlu diperhatikan pada bahwa penekanan pada karakter "kreatif" ini kemudian bisa menjadi bumerang, antara lain:

a) membuat kerentanan atau hilangnya jaminan kerja, pemasukan stabil, akses yang makin berkurang pada pensiun, tanggungan kesehatan, eksploitasi, dan hilangnya perlindungan dari syarikat

b) Kondisi ini tidak terlalu menciptakan masalah bagi tenaga kerja yang memiliki banyak koneksi, jaringan atau modal ekonomi yang baik, tapi bisa makin mengisolasi mereka yang tidak memiliki akses tersebut.

c) Kerja kreatif seringkali membutuhkan mobilitas, jaringan sosial (pertemanan dan kenalan) dan akses informasi. Masalahnya kita tahu sendiri bagaimana buruk dan tidak meratanya infrastruktur transportasi dan komunikasi umum di Indonesia.

d) Utopia wacana "kreatif" yang menekankan "kreatifitas individu" sadar tidak sadar malah mengalihkan perhatian dari kebijakan struktural seperti ketimpangan kondisi hidup, ketimpangan kondisi kerja, dan kesemrawutan fasilitas umum mendasar seperti air bersih, listrik, transportasi, dsb. Padahal ini masalah mendasar yang perlu diperhatikan dalam penerapan kebijakan (Richard Florida, 2012)

\section{Creative Hub}

Pengertian Creative Hub Menurut Creative HubKit, creative hub adalah tempat, baik fisik maupun virtual, yang menyatukan orang-orang kreatif dan berperan sebagai penghubung yang menyediakan ruang dan dukungan untuk menjalin koneksi, pengembangan bisnis dan keterlibatan masyarakat dalam sektor kreatif, budaya dan teknologi. Pusat kreatif memiliki berbagai tujuan:

a) Untuk memberikan dukungan melalui layanan dan / atau fasilitas untuk gagasan, proyek, organisasi, dan bisnis yang menjadi tuan rumah, baik dalam jangka panjang maupun jangka pendek, termasuk acara, pelatihan keterampilan, pengembangan kapasitas, dan peluang global.

b) Untuk memfasilitasi kolaborasi dan jaringan di antara komunitasnya.

c) Untuk menjangkau pusat penelitian dan pengembangan, lembaga, industri kreatif

d) Untuk berkomunikasi dan terlibat dengan khalayak yang lebih luas, mengembangkan strategi komunikasi aktif.

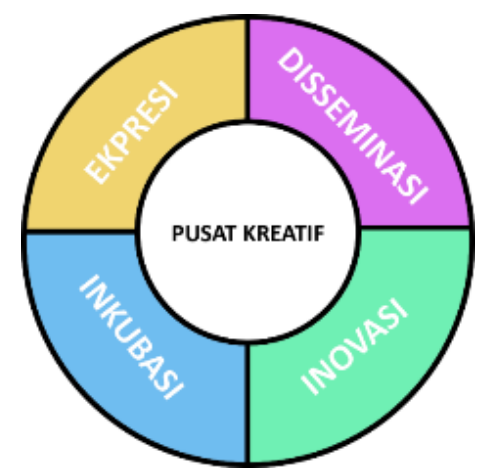

Gambar 1. Konsep Kreatifitas

Sumber: http://ayorek.org/2013/08/kota-kreatif-sejarah-singkat-dantantangannya/\#sthash.GKq0oDb7.q4yp34XX.dpbs. 2013 
a) Ekspresi : Memberi ruang kepada individu, komunitas, dan usaha untuk mengekspresikan kreativitasnya, sehingga iklim kreatif tetap terpelihara.

b) Diseminasi : Tempat berkumpul (meeting point \& sharing) pelaku kreatif. Ide-ide bisnis kreatif baru diyakini akan tumbuh ketika antarpelaku kreatif sering berdiskusi dan sharing.

c) Inovasi

- Klinik HKI (Hak Kekayaan Intelektual): sosialisasi dan fasilitasi pendaftaran HKI

- Direktori Inovasi: meningkatkan akses pelaku kreatif Indonesia terhadap hasil-hasil inovasi dari lembaga riset yang ada di Indonesia

- Sentra Inovasi: tempat melakukan eksperimen-eksperimen inovasi

d) Inkubasi

- Creative Office: fasilitas kantor bersama untuk usaha pemula (startup)

- Klinik Konsultasi: pendampingan mengenai kewirausahaan oleh mentor yang tepat

- Workshop: pelatihan teknis, manajemen, dan kewirausahaan.

- Pembiayaan: memfasilitasi peningkatan akses pengusaha, khususnya startup terhadap lembaga pembiayaan

- Business Connect: pitching pengusaha pemula dengan investor (angel investor).

\section{METODE}

Tjahjono, G. (2000).

Metode Fenomenologi

Dengan menggunakan suatu prosedur kognitif yang khusus. la berdasarkan intuisi dalam pengamatan intelektual terhadap objek yang akan di rancang. Intuisi ini mengacu pada aturan utama yaitu "kembali kepada benda itu sendiri " dalam hal ini, benda itu berarti yang diberikan untuk melaksanakan 3 reduksi

\section{Metode Tipologi}

Mengkaji suatu obyek dengan tipe, yang sebagai arti kata type dalam bahasa Inggris, berasal dari kata Yunani tupos yang bearti tanda atau suatu kesan yang ditimbulkan secara keras. Lalu dalam beberapa saat ini kata tipe dipakai dalam beberapa keadaan yang menunjukan, antara lain sebagai sifat umum suatu bentuk, kategori, jenis, aturan, contoh, dan model.

\section{Metode Shape Grammar}

Dengan menggunakan pendekatan yang berasosiasi dengan Bahasa dalam menyelesaikan rancangannya, ada yang secara sadar dan sistematis, ada yang tidak sadar, tetapi terbaca. Dengan mengamati tata Bahasa yang berada di dalam suatu obyek dan memasukan variabel baru dalam konteksnya, maka didapatkan hasil yang bernafaskan tata pikir obyek yang tersebut.

Pada akhirnya manusia akan berdasarkan symbol terakhir. Konteks perancangan ditentukan oleh seluruh proses yang berjalan.. Receptors. Sedangkan olahan yang terjadi pada tahap kedua berpikir adalah bagian urusan teori (theory), dan dalam tahap terakhir, bagian Bahasa (language) yang berurusan dengan penerjemahan. Disitulah semua aturan disusun, kemudian dari situ simbol-simbol dikembalikan ke bagian teori untuk penjelasannya. Dan terkahir akan keluar tindakan yang dia sebut sebagai effectors.

\section{DISKUSI DAN HASIL}

Berikut merupakan hasil analisa dan rancangan berupa analisa makro \& mikro, denah, tampak, dan potongan dengan menggunakan konsep berkelanjutan dan menjawab tipe, perilaku, dan kesejamanan. 

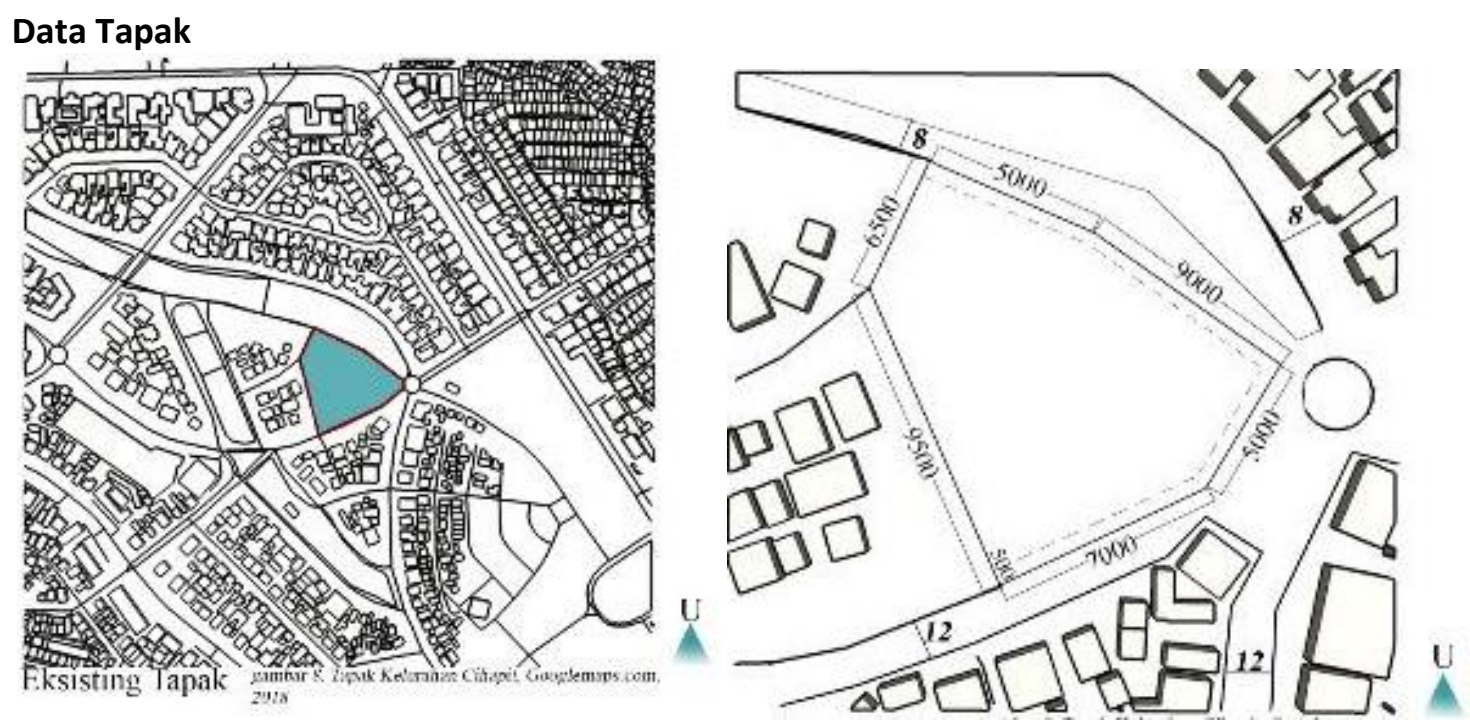

Gambar 2. Peta Kawasaan Kelurahan Cihapit Sumber: Penulis, 2019

$\begin{array}{lll}\text { KDB }: 30 \% & \text { Batas Utara } & : \text { Pet Park } \\ \text { KLB }: 1.24 & \text { Batas Timur } & \text { : Restoran Shabu Hachi } \\ \text { KDH }: 60 \% & \text { Batas Selatan } & \text { : Perumahan Sedang } \\ \text { KB }: 3 & \text { Batas Barat } & : \text { Streetfood } \\ \text { GSB }: 6 \mathrm{~m} & & \end{array}$

\section{Data Kawasan}

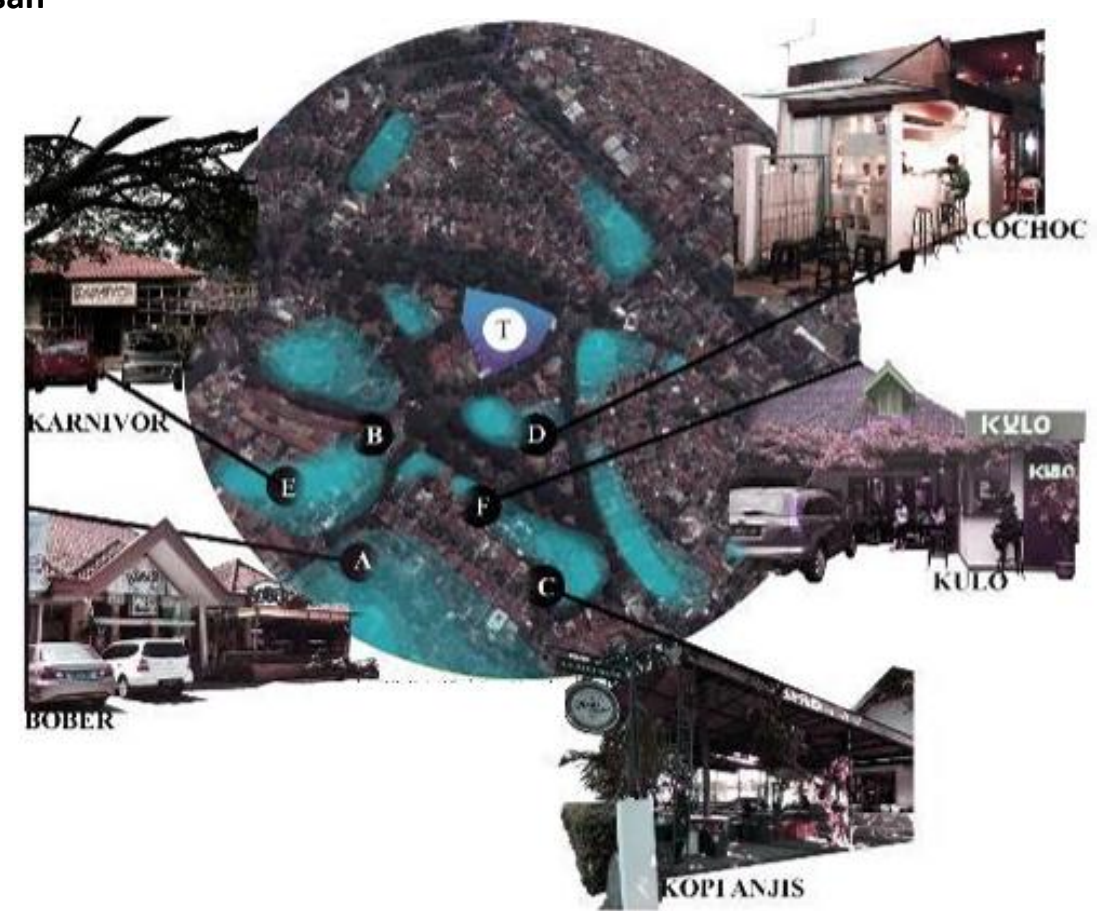

Gambar 3. Peta Titik Kafe dan Restoran Sumber: Penulis, 2019

Badan Statistik Kota Bandung (2018). Ada Kurang lebih 150 Restauran dan kafe disekitar tapak dengan Radius 500m Dengan rata-rata kafe dan restauran berjarak 100, dan belum termasuk kios-kios daerah kecamatan Cihapit merupakan kecamatan yang cukup padat oleh tempat kuliner dari kafe kecil sampai restoran berbintang. 


\section{Data Aktivitas Kawasan}
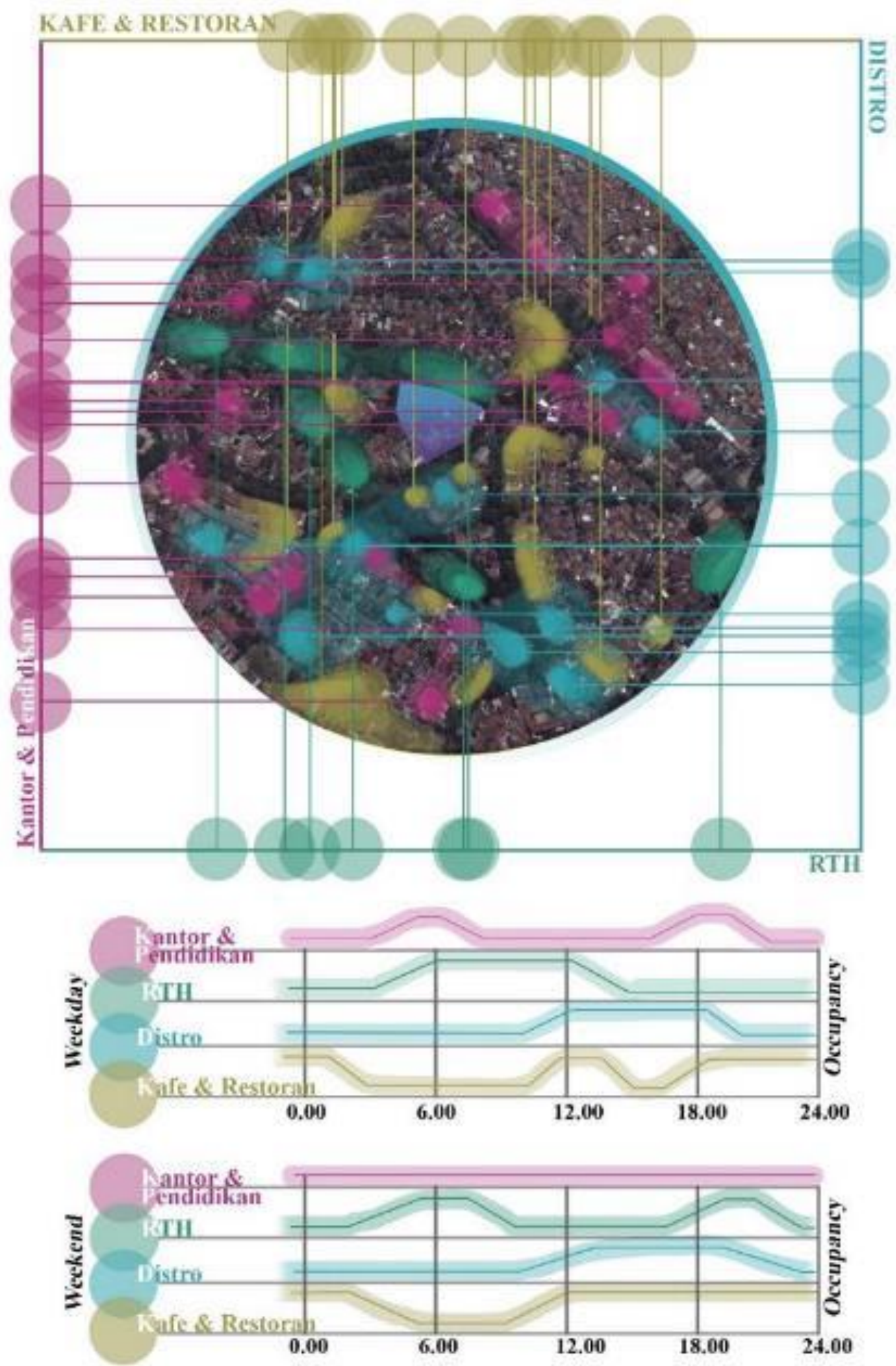

Gambar 4. Analisa Aktivitas Kawasan

Sumber: Penulis, 2019 


\section{Proses Gubahan Masa}

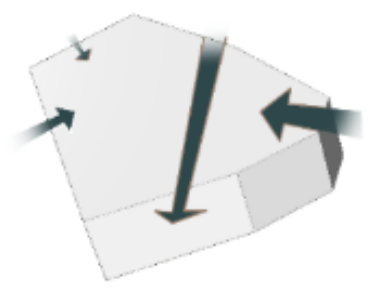

Axis Sirkulasi, dengan mengambil axis pejalan kaki dan axis bangunan sekitar tapak.

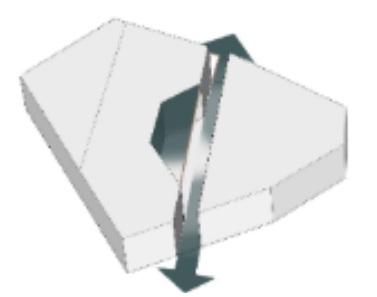

Membelah, Dengan memberikan axis sirkulasi dari berbagai arah sekitar tapak, mendapatkan hasil gubahan dan membelah pada bagian sirkulasi yang terpotong dengan gubahan.

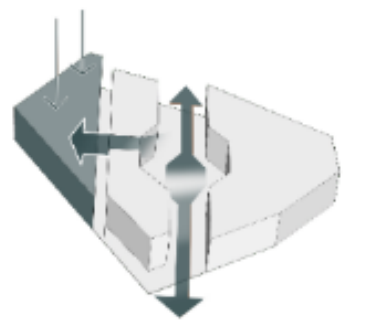

KDH 50\%, Karena peraturan yang terdapat di wilayah kel.Cihapit yaitu dengan menyediakan kdh minimal $60 \%$ menjadikannya bangunan yang cukup dipenuhi oleh penghijauan.

Membelah, Void pada bagian tengah untuk pengunjung berkumpul dan berbincang bersama dan bertukar pikiran.

\section{Gambar 5. Proses Gubahan Masa}

Sumber: Penulis, 2019

\section{Analisa Aksesibilitas Tapak}

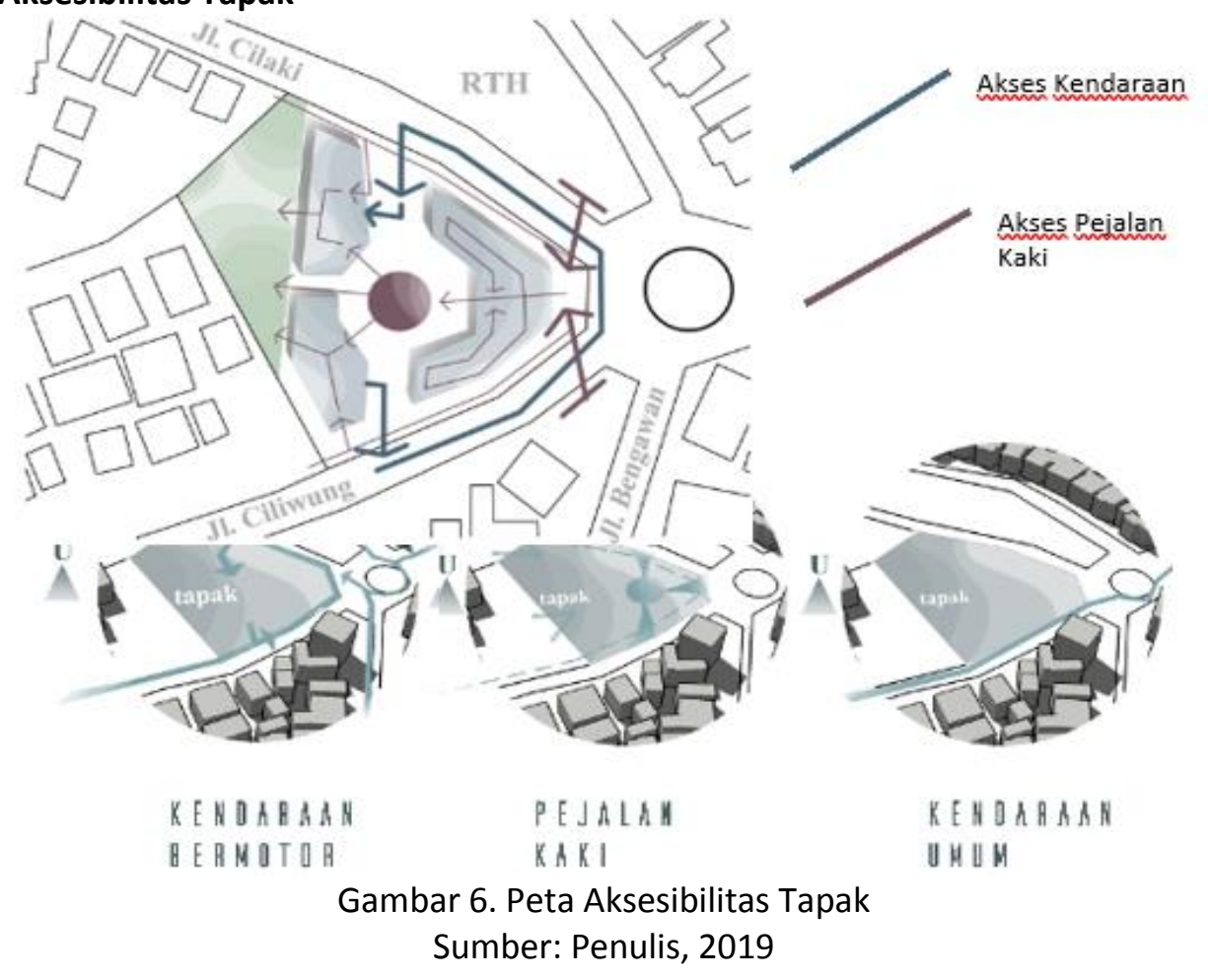


Dengan membuat akses pintu masuk pejalan kaki di setiap arah dan setiap bagian untuk mempermudah akses pejalan kaki saat memasuki tapak.Pejalan kaki akan bertemu dan berkumpul pada titik merah pada bagian tapak.dan dapat langsung mengakses courtyard belakang tapak langsung tanpa harus masuk kedlam bangunan Akses Kendaraan bermotor pada bagian utara untuk pintu masuk dan selatan untuk pintu keluar

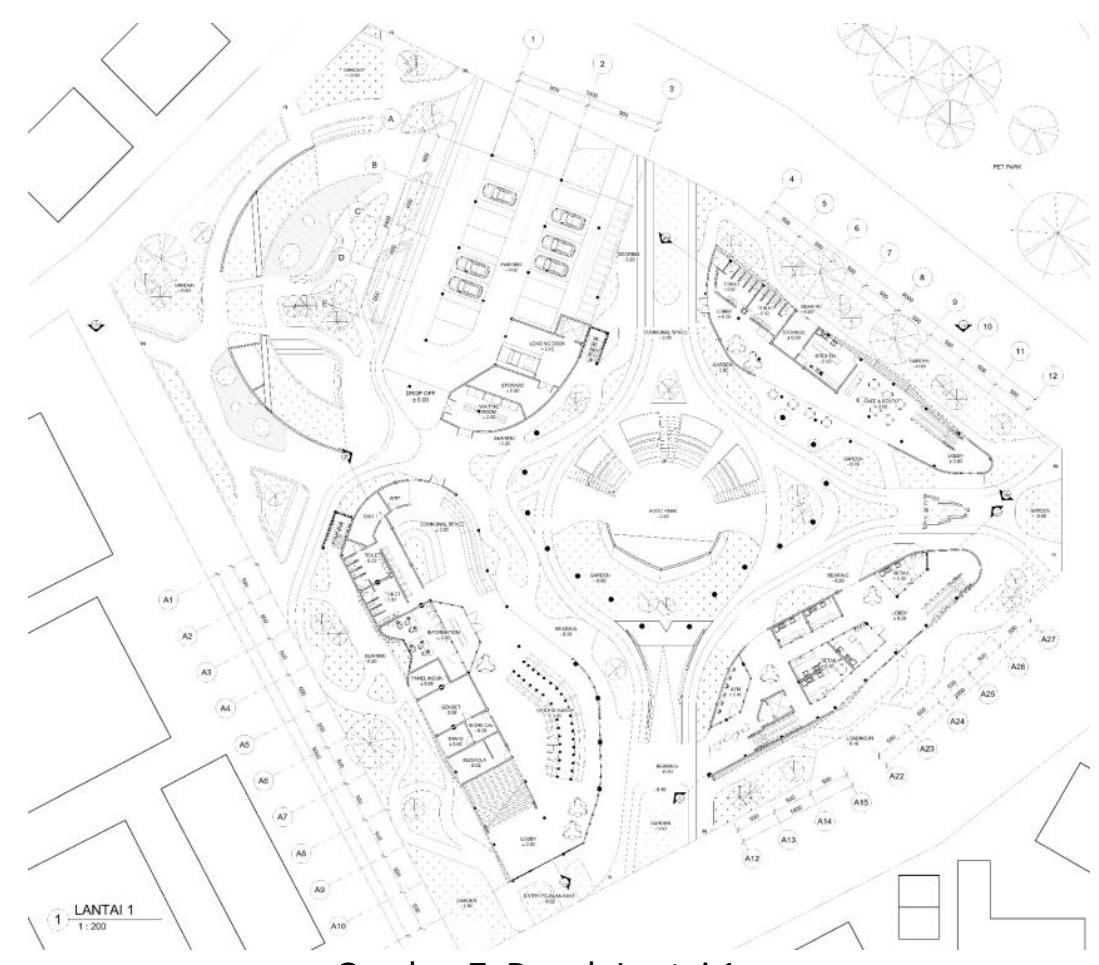

Gambar 7. Denah Lantai 1

Sumber: Penulis, 2019

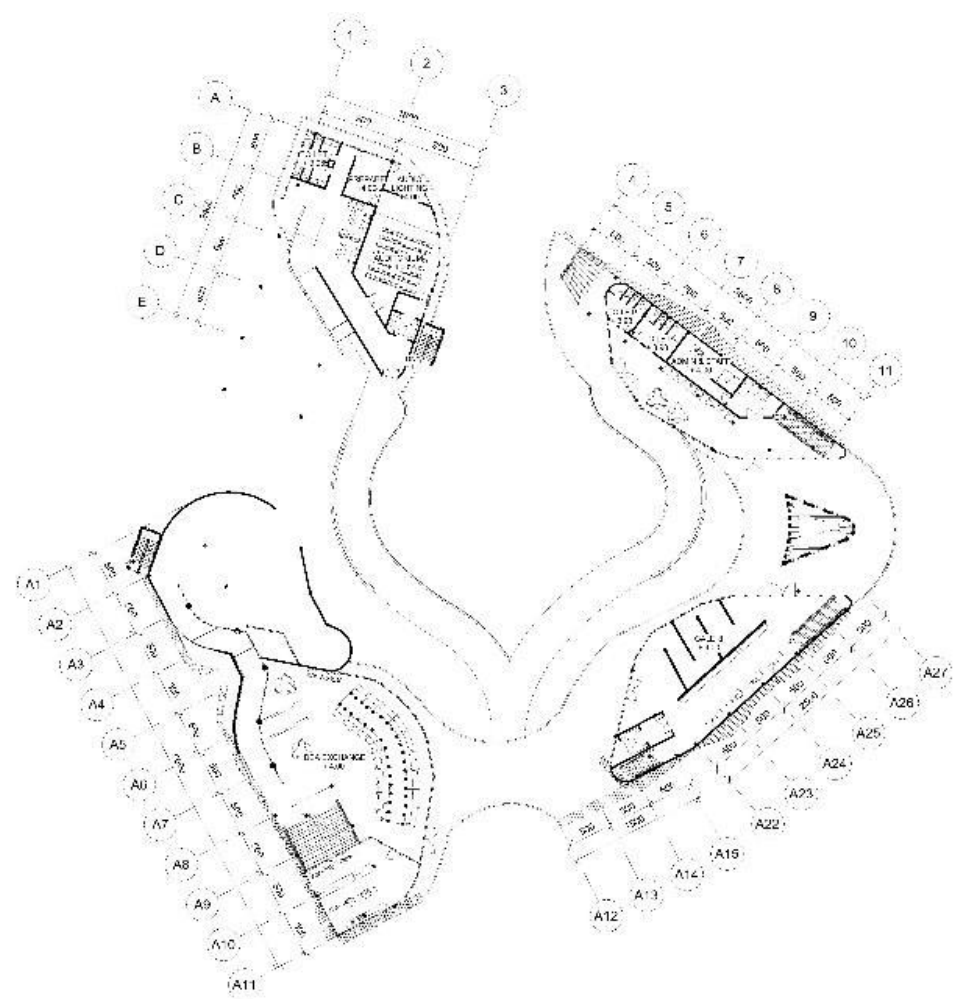

Gambar 8. Denah Lantai 2

Sumber: Penulis, 2019 


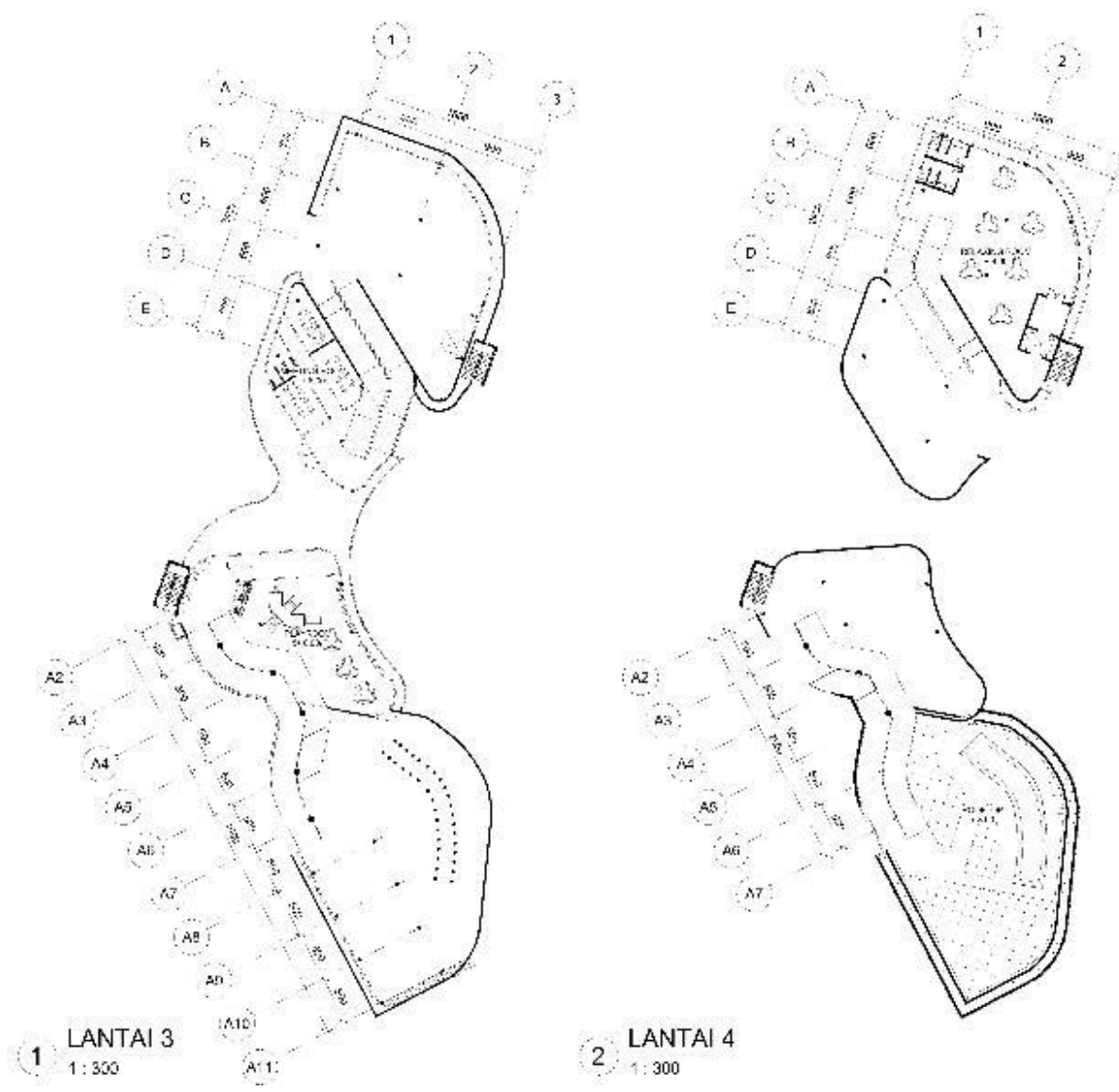

Gambar 9. Denah Lantai 3 \& 4

Sumber: Penulis, 2019
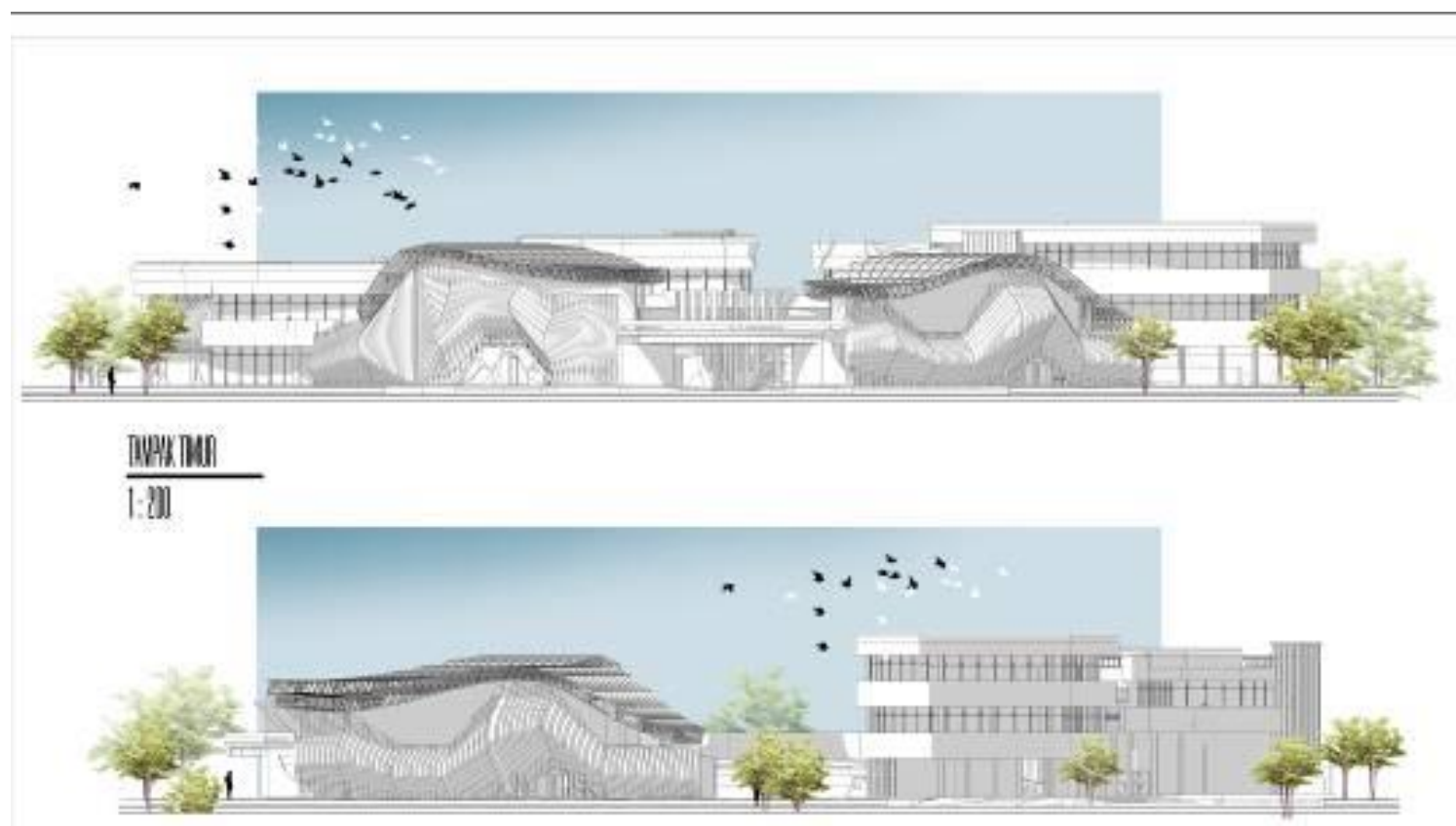

WWHIIIH

Gambar 10. Tampak Timur \& Utara

Sumber: Penulis, 2019 

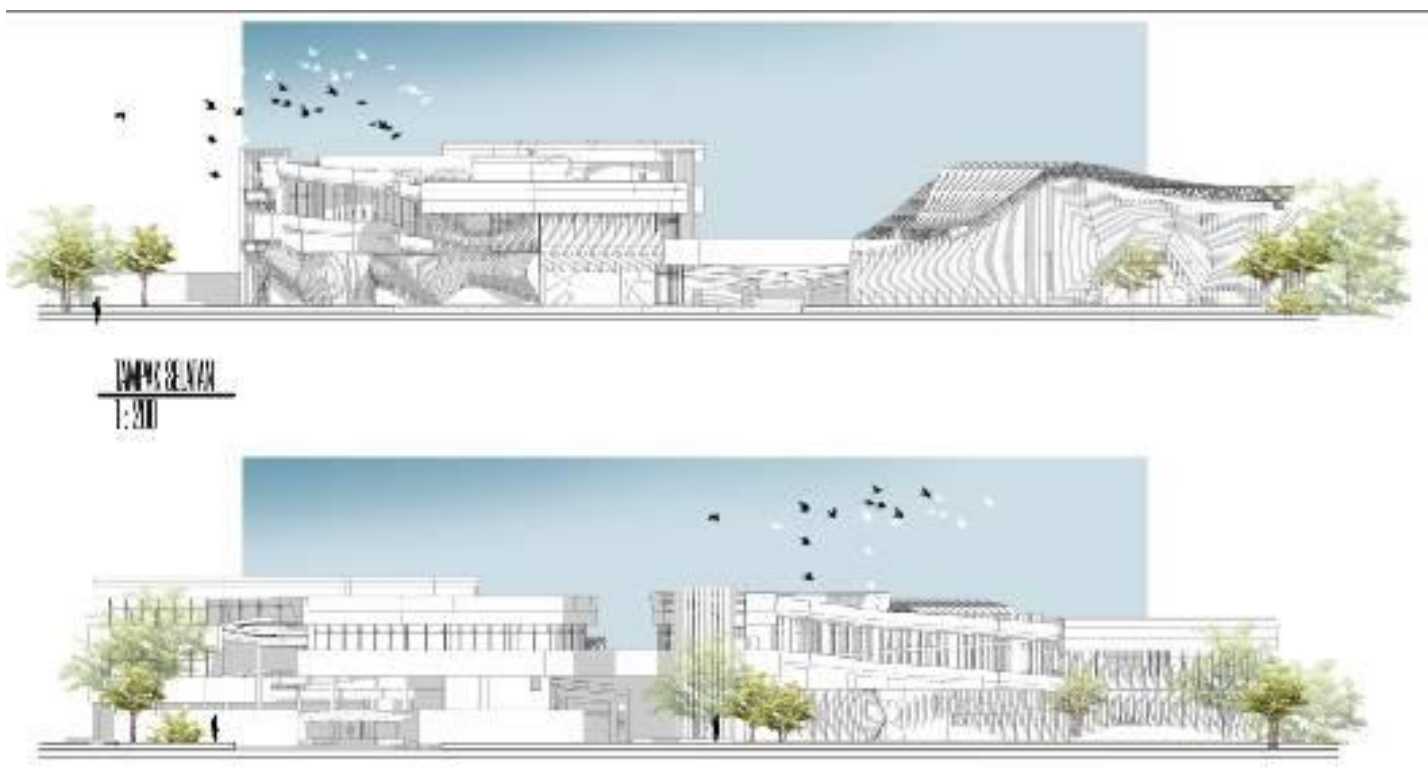

TWH HWH

Gambar 11. Tampak Selatan \& Barat

Sumber: Penulis, 2019
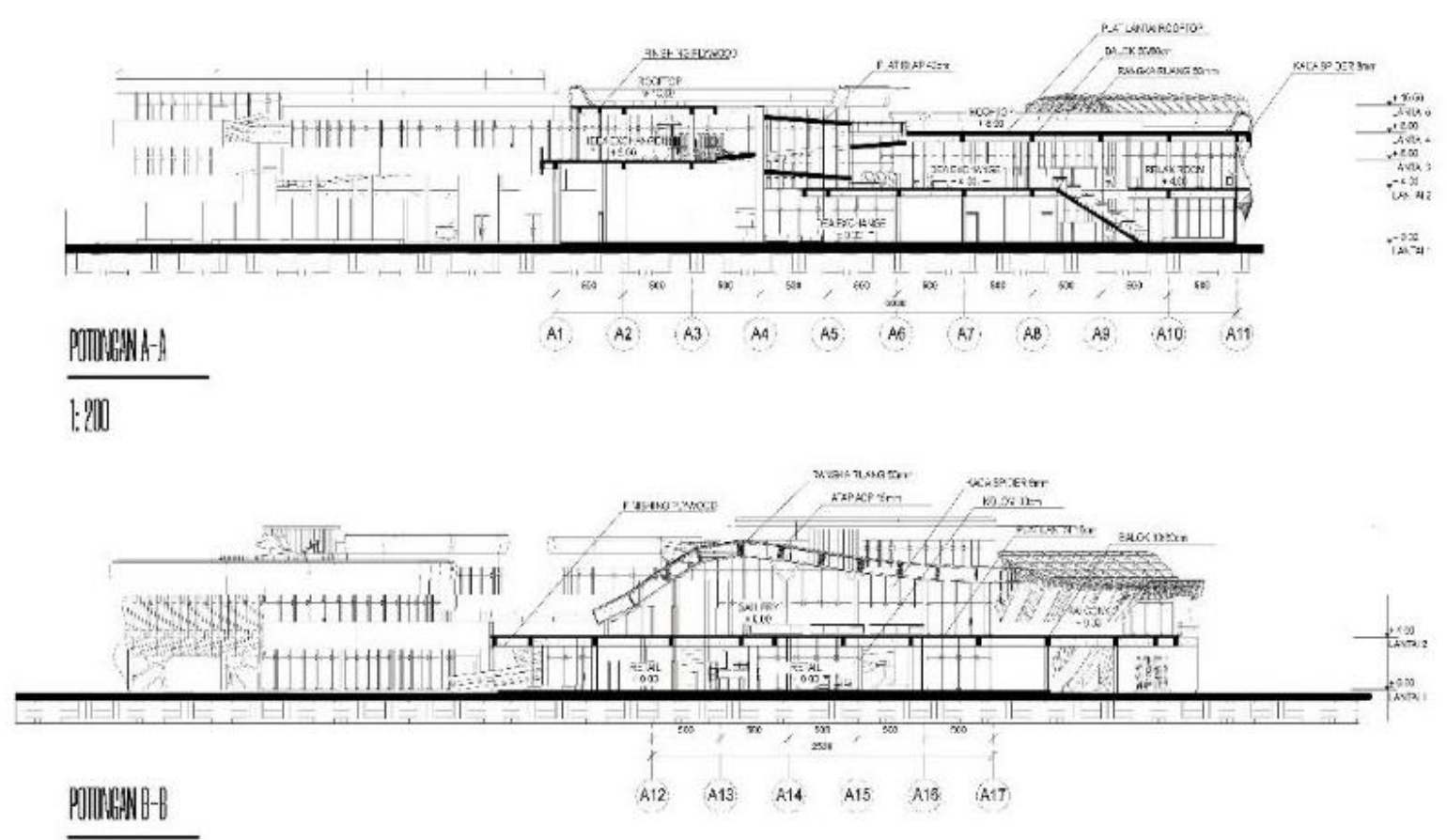

Gambar 12. Potongan AA-BB

Sumber: Penulis, 2019 


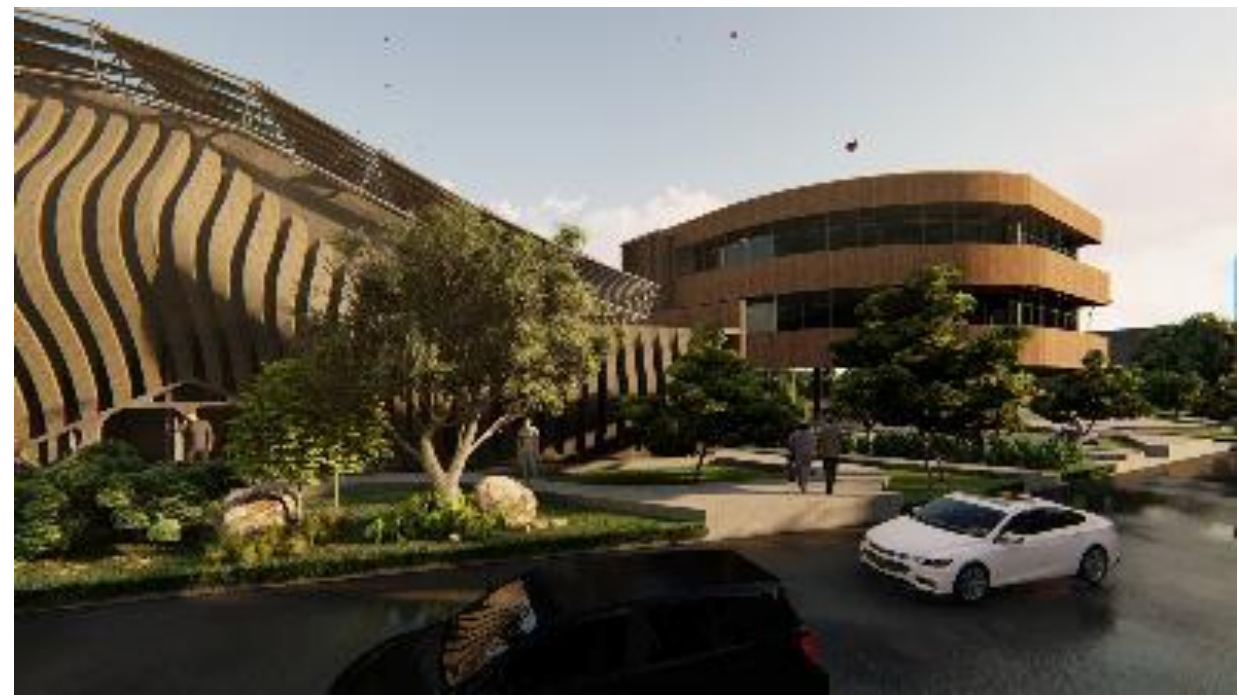

Gambar 13. Perspektif Exterior

Sumber: Penulis, 2019

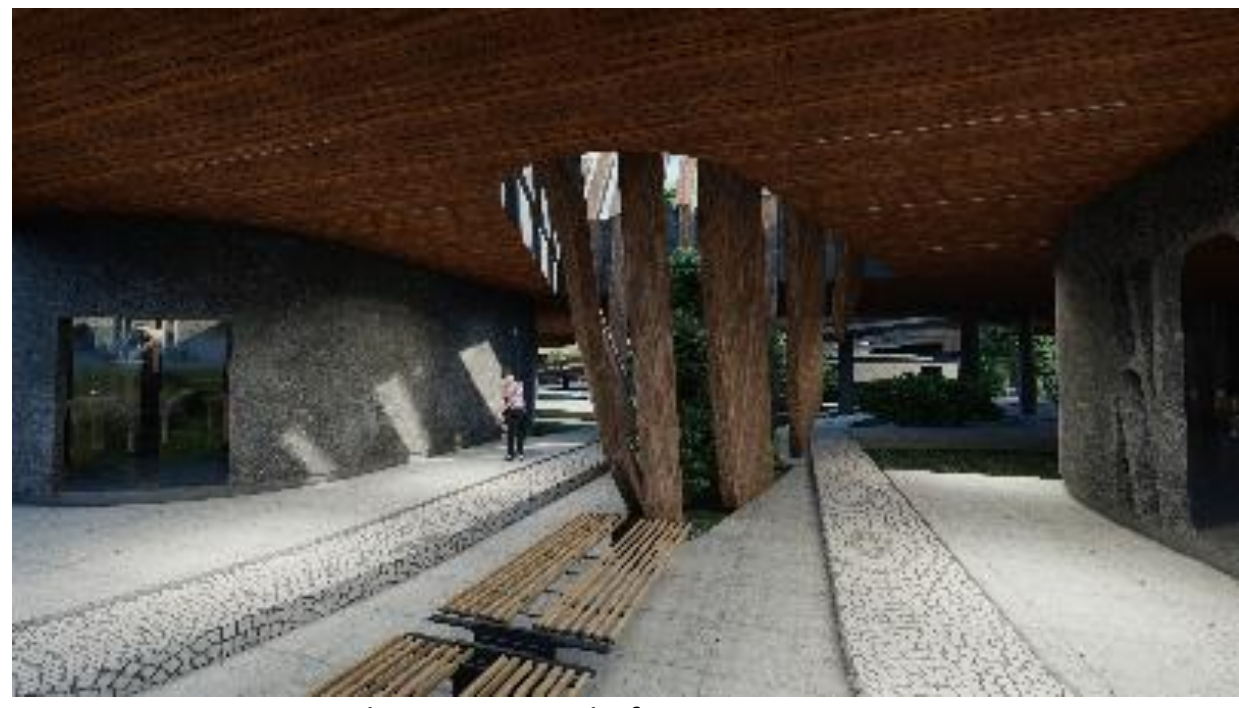

Gambar 14. Perspektif Interior Entrance

Sumber: Penulis, 2019

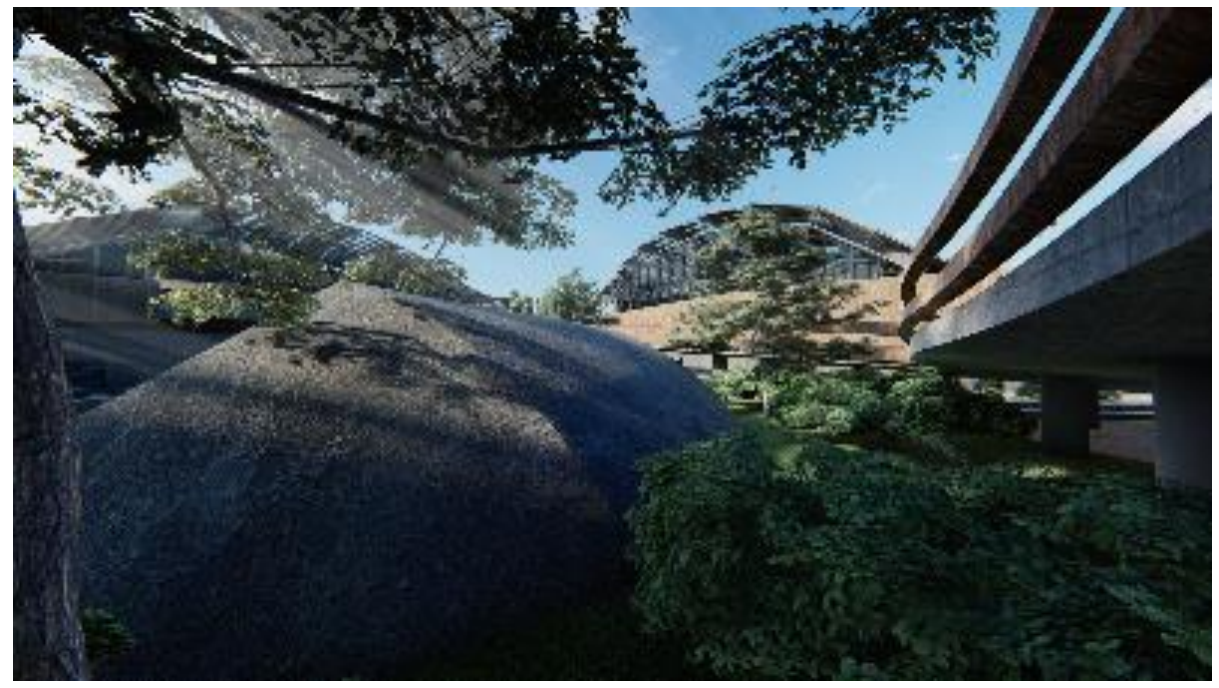

Gambar 5. Perspektif Exterior Foodpark

Sumber: Penulis, 2019 


\section{KESIMPULAN DAN SARAN}

Idea Exchange Center bertujuan dengan dibangunnya third place ini akan membantu pembangunan kebutuhan masyarakat kota dan juga ekonomi kota dalam beberapa tahun kedepan, dengan menaikan ke-kreatifitas masyarakat wilayah Bandung Wetan, khususnya Kelurahan Cihapit akan menaikan kualitas kerja, belajar, maupun produk-produk yang dihasilkan oleh masyarakat. Dalam desain Idea Exchange Center ini dibutuhkan fasilitasfasilitas yang mendukung dan juga berhubungan dengan Program utama Idea Exchange Center seperti Foodpark, Kafe, Retail, sebagai cara untuk menarik pengunjung untuk datang khususnya para desainer. Idea Exchange Center tidak memiliki batsan untuk pengunjung yang akan datang dan menggunakan fasilitas yang telah disediakan, Penggunaan bahan-bahan bangunan haruslah yang ramah lingkungan dan harus mengembalikan tema hijau karena di sekitar tapak terdapat taman kota yang rimbun dan sangat mempengaruhi bangunan sekitar.

Dengan dibangunnya third place ini akan membantu pembangunan kebutuhan masyarakat kota dan juga ekonomi kota dalam beberapa tahun kedepan, dengan menaikan ke-kreatifitas masyarakat wilayah Bandung Wetan, khususnya Kelurahan Cihapit akan menaikan kualitas kerja, belajar, maupun produk-produk yang dihasilkan oleh masyarakat.

\section{REFERENSI}

Council, B. (2017). Creative Hub. Indonesia: Centre for Innovation Policy and Governance. Florida, R. (2014). The Rise of The Creative Class. New York, United States: Ingram Publisher Services.

Oldenberg, R. (1999). The Third Place. New York: De Capo press.

Tjahjono, G. (2000). Metode Perancangan . Depok: Universitas Indonesia.

Badan Statistik Kota Bandung (2018). Kecamatan Bandung Wetan Dalam Angka 